\title{
ASSESSING THE IMPACT OF IRRIGATION IMPROVEMENT PROJECTS ON WATER SAVING, CROPS YIELD AND ENERGY COST - CASE STUDY: AL-ATF CANAL, EGYPT Talaat El Gamal ${ }^{1}$ and Hanan Farag ${ }^{2}$ \\ 1 Associate Professor, Water Management Research Institute (WMRI), National Water Research Center (NWRI), Ministry of Water Resources and Irrigation (MWRI), E- Mail: elgamalt@gmail.com \\ 2 Associate Professor, National Water Research Center (NWRI), Ministry of Water Resources and Irrigation (MWRI); E-Mail: hananfarag71@gmail.com
}

Key Words: Water Saving, Energy Cost, Irrigation Improvement Projects, Water Management, Water Use Efficiency

\section{ABSTRACT}

Egypt is an arid country with limited water resources. There were also some problems regarding energy resources during last years. In Egypt, both water and energy are tightly connected to food production, as agricultural depends totally on irrigation, and the Egyptian irrigation system imposes lifting water from watercourses to the surrounding fields. With the rapid population growth in Egypt, there is a necessity to produce more food, and this requires optimizing the use of limited water and energy resources. Irrigation Improvement Projects (IIPs) were among the solutions to improve water and energy use and increase water productivity. The projects should improve water productivity by improving water use efficiency and crops yield. Another important objective for IIPs was to decrease the irrigation cost through the optimal use of the energy. After the actual implementation, the evaluation of IIPs referred to difficulties in the achievement of some objectives, while other objectives were achieved successfully. The current study presented the current situation of water, energy, and food in traditional situation in Egypt and the expected impact from IIPs on these elements, and then it investigated the actual impact of IIPs after the implementation. An improved canal in the Middle Delta (Al-Atf canal) was selected for such investigation. The measurements were conducted in the first reach of the canal. Measurements on the canal did not refer to real change in water use efficiency, mainly due to the unsuitable operation of the irrigation system and the lack of coordination between farmers. Regarding the energy, the single-point lifting and the dependence on the electric power had a significant impact on reducing the irrigation cost. The study discussed the reason for low water use efficiency, and it suggested 
developing an operation model that calculates actual water requirements based on remote sensing information to propose the optimal operation scenario for the improved Mesqas. Such model could improve water management, which should have positive impact on water use efficiency, and in consequence on irrigation cost.

\section{INTRODUCTION}

The connection between water, energy and food production (agriculture) is obvious. Water is the basis for food production, and it is also used for energy production (hydropower) and even it share in thermoelectric power plants through cooling of these plants. Energy is another main element in food production, starting from cultivation (irrigation and agricultural machinery) to food industry and food distribution. Energy is also used for water abstraction, processing and distribution (pumping and extracting water for different purposes, treating wastewater, and the desalination of seawater). Such interconnected relationship has other dimensions with the limitation of the resources. Such limitation requires optimal use of different elements and therefore the integrated approach became more important.

In Egypt, water and energy resources were not only limited, but also they are threatened by the rapid population growth that requires more resources, and therefore the situation became more critical. Tackling such problem could have many axes, and one of the introduced solutions for better use of water and energy for agricultural purposes was the Irrigation Improvement Projects (IIPs). Some previous studies were conducted to evaluate the impact on improving food production and saving water and energy. The evaluation programme that was conducted by Water Management Research Institute between 2002 and 2018 developed many evaluation reports. Different methodologies were used to evaluate the three elements [ $13 \& 14 \& 15 \& 16]$. El-Gamal, T. discussed the impact of IIP on water saving [1 \& 2]. Nour El-Den and Kotb discussed the impact of IIP and change in electrification on saving the energy in Egypt [12]. The current study provides an integrated approach that to assess water and energy use and their impact on food production in the improved areas.

\section{Objective}

The objective of the current study is to evaluate the impact of IIPs on the rational use of water and energy in the agricultural field, and their impact on food production to define the next steps for this approach, and if it should be continued, adapted or stopped. 
Methodology

The current followed the following approach:

- First, the study discussed the situations of water, energy and food in Egypt. It discussed their availability, the change in their consumption trends, and the interrelation between them

$\square$ Second, the study discussed the impact of Irrigation Improvement Projects (IIPs). The discussion included the expected impact as was presented in literature review, and the actual impacts as presented in previous evaluation programmes.

- Then, the study investigated the impact of IIPs on the study area (ElAtf canal). The investigation included the impact of IIPs on crop yields, water use and irrigation cost. The investigations of these items were as follows:

- Regarding the impact of IIP on crop yields, the results were collected from framers through questionnaires samples.

- Regarding the impact of IIP on water use, the discharges were measured at the head and the tail end of the study area. The measurements at the head were used to check the validity of weir equations. Measurements at the tail end of the study area were used to develop a new stage-flow relationship. Weir equation at the head and the developed relationship at the tail end were used to calculate water use in the study area. Water consumption was calculated using remote sensing technique.

- Regarding the impact of IIP on the irrigation cost, questionnaire samples were used to define average irrigation cost for different crops before and after irrigation improvement. In addition, detailed information for some Mesqas were used for precise calculation of the irrigation cost.

\section{The Current Situations of Water, Energy and Food in Egypt}

The availability of Water, Energy and Food in Egypt

Food Gap in Egypt

Along the history, Egypt was known as "World's bread basket". However, and with the rapid population growth in the modern history, food production began to be insufficient, and Egypt began to depend on external imports to fill the food gap. According to Gamal Hemdan (1984), "Throughout the 1960s, the food gap was relatively moderate, but it exploded in the 1970s, nearly tenfold in just 10 years, and it included all crops except rice, vegetables and fruits". He described the situation for the wheat as follows, "Self-sufficiency of wheat continued until 1945. From 1950 to 1970, local production covered the rural residents, while urban residents relied on external imports. Since 1975, the stage of national inefficiency has begun. Since then, both rural and urban areas began to depend on external imports." Mady (2014) illustrated that there 
was a food gap in meat, wheat, and legumes, and the gap was increasing. From 2000 to 2010, the food gap for meat, wheat and legumes increased by $53.1 \%, 35.6 \%$ and $1.7 \%$ respectively. For sugar, vegetables and oil, the production was exceeding the consumption. However, the production surplus of these goods decreased during the same period by $2.8 \%, 17.4 \%$ and $44.8 \%$ respectively. Only for fruits, the production surplus increased during this period (2000-2010) by $44.3 \%$.

\section{Water Resources \& Water Use}

There was a rapid reduction in per capita share of water in Egypt. The values, which were exceeding $2000 \mathrm{~m}^{3} /$ capita at the middle of the previous century, dropped to less than $700 \mathrm{~m}^{3} /$ capita in last years. Based on MWRI (2017), total water supply in Egypt in 2015 was 59.25 BCM. From this amount, municipal sector used $10.75 \mathrm{BCM}$, and 5.4 BCM was used by the industry sector. Total consumption from both municipal and industry sectors was around 3.78 $\mathrm{BCM}$ and around $12.37 \mathrm{BCM}$ return to the system as polluted losses. Considering that there was around 2.4 $\mathrm{BCM}$ evaporated from the water surfaces, the share of the agricultural sector was around $40.7 \mathrm{BCM}$, which is very close to the required consumption (40.0 BCM as estimated in the report). However, the actual water use of the agricultural sector is $61.1 \mathrm{BCM}$ thanks to the intensive reuse of water losses.

\section{Energy Resource}

The energy sector in Egypt is now improving after a period of suffering. The main improvement was in the production of the natural gas. Based on Hussein and El Baz (2018), "Egypt's natural gas production was almost stable between FY 2010/11 and FY 2011/12, with a slight decrease from approximately 46.3 million tons equivalent per year (mtoe/y) to 46.07 mtoe/y. Since FY 2012/13, the level of production has been declining steadily. Annual production reached its lowest level of $31.3 \mathrm{mtoe} / \mathrm{y}$ in FY 2015/16, before recovering slightly to $31.9 \mathrm{mtoe} / \mathrm{y}$ in FY 2016/17'. It is expected that Egypt will return to exporting the natural gas from 2019-2020.

For the electricity, the production increased annually to face the gradual increase in the demand regardless the source of the fuel (nationally or imported). From figure (1), generated electricity increased gradually from $110,299 \mathrm{GWh}$ in $2004 / 2005$ to $189,550 \mathrm{GWh}$ in 2016 2017. The highest annual increase ratio was $8.4 \%$ in $2006 / 2007$. The lowest increase ratios were $1.7 \%$ in $2016-2017$ and $2.4 \%$ in $2012-2013$ [9].

\section{The change in the consumption trends of Water, Energy and Food in Egypt}

There was a fast change in life standard in Egypt during last decades. This affected the consumption trends, and it increased the difficulty of 
optimizing water and energy use. Based on Mady (2014), "The situation of agriculture and food in the current period (2001-2012) has reached a critical stage that was represented in the growing demand for agricultural products due to the population increase in addition to the general trend of consumption increase despite the increase in the prices". Consumption increase resulted in the increase of food waste despite the food gap in Egypt. Some international organizations stated that Food Losses and Waste (FLW) in Egypt are high, especially for perishable products [4].

Regarding water use, municipal water increased from 3.1 BCM in 1990 ( 170 liter/capita) to 10.75 BCM in 2015 (327 liter/capita). Based on MWRI (2017), the last value (for 2015) is much higher than the normal per capita consumption. For irrigation, the inability to control the system in last decades resulted in misuse of water. Irrigation Development Plan in Egypt stated that water duty increased during 1970's from $16429 \mathrm{~m}^{3} /$ ha to $19047 \mathrm{~m}^{3}$ /ha due to the misuse of water [10]. However, and as the system is considered as a closed system, the problem is in wasting the water and reusing water losses. The water losses is polluted, after mixing with sewage and industrial wastes, and therefore it has negative impact on crop production besides the health risk. Moreover, using the water more than one time is associated with more energy consumption.

For the electricity use, average energy used per capita increased from $1650 \mathrm{KWh}$ in 2006/2007 to $1910 \mathrm{KWh}$ in 2011/2012 [9].

The Relation between Water, Energy and Food in the Traditional Situations in Egypt

The relation between agricultural and water is obvious as agriculture depends principally on water. In Egypt, there is almost a complete dependence on the irrigation, as the rain is rare. Some investigations reported the Egyptian irrigation system as the third for land productivity among 56 investigated irrigation systems, but it was the tenth among these investigated irrigation systems for water productivity, which refer to low irrigation efficiency compared to the other irrigation networks [3]. Regarding the future relation between water and agricultural, the gradual increase in municipal and industrial water use will have a vital impact on the agriculture sector as the current share of agriculture of the fresh water is close to total crop consumption. The future scenarios to improve the relation between water and agricultural contains treating the wastes of these sectors to make use of these big amounts of water, and decreasing the dependence on the reuse by improving water use efficiency. The last scenario was one of the main objectives of IIPs. Another scenario is to produce more crops with the same amount of water through producing new crop varieties. 
Agricultural (producing food) has a tight relationship with the energy as well. Besides agricultural machinery and food industry, there is a high dependence on the energy in irrigation sector, after diesel pumps have replaced animal-driven wells (Saqias) for lifting the irrigation water in the end of 1970's. The huge volume of water is currently lifted by farmers' diesel pump, consuming an estimated amount of about 700,000 tons of diesel fuel annually [12]. The irrigation cost, based on the statistics for 2016, constituted between $4 \%$ and $10.3 \%$ of the agricultural inputs, coming after the agricultural machinery that constituted between $5.9 \%$ and $15.9 \%$ of these inputs [8]. For the future relationship between agricultural and energy, there is a trend to use the electricity in agricultural, and this is likely connected to irrigation and the implementation of the new phases of IIPs that relied on the electric power. Total electricity sold for agricultural purposes increased from $2967 \mathrm{GWh}$ in 2006/2007 to $6033 \mathrm{GWh}$ in 2016/2017 [9]. This constituted between $2.6 \%$ in $2006 / 2008$ and $3.8 \%$ in 2013-2014 (figure $1)$.

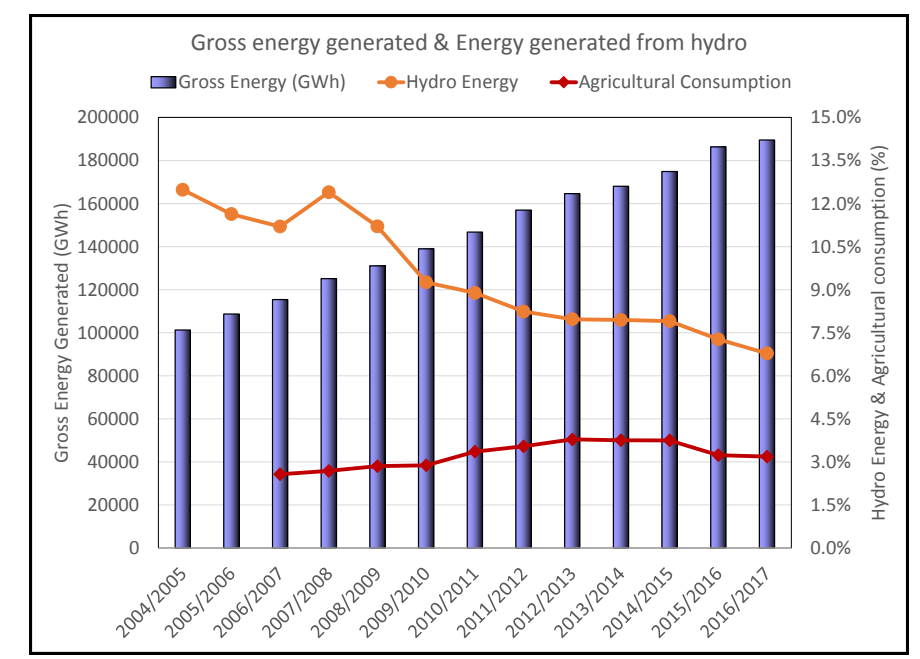

Figure (1): Total generated electricity, the share of Hydropower, and the ratio of the electricity sold for agricultural purpose in Egypt (After MEE, Annual electric reports)

For the relation between water and energy, the dependence on hydropower started in Egypt before the middle of the previous century. With the construction of High Dam, the ratio of the hydropower exceeded 50\% of total generated electricity in Egypt in 1970's. This affected the released water from High Dam, and therefore some fresh water was dumping into the sea during this time. The importance of the hydropower decreased gradually since 1970's until now with the construction of thermal power plants. From 2004-2005 to 2016-2017, the 
annual electricity produced from the hydropower was between 12644 and $15510 \mathrm{GWh}$ [9]. This constituted between 12.5\% (in 2004-2005) and $6.8 \%$ (in 2016-2017) from total generated electricity during this period (figure 1). It is expected that the relationship between water and energy will be flipped in the future. Previously, water was the main source to generate energy. In the future, the energy will be an essential source to generate water, through the extraction of deep groundwater and the treatment of the polluted and brackish water.

\section{The Impact of IIPs on Water, Energy and Food Elements}

The Expected Impact of IIPs on Water, Energy and Food Elements

The idea of Irrigation Improvement Projects (IIPs) were started in Egypt in 1970's through a research project in Water Management Research Institute (Egyptian Water Use and management Project EWUP). With the execution of IIPs, there was an expectation that the projects could contribute in considerable amount of water saving. For example, the strategic plan (1997-2017) for Ministry of Water Resources and Irrigation contained improving 1.5 million feddan until 2025, which will result in saving 1070 million $\mathrm{m}^{3}$, and the appraisal document of IIIMP expected that water savings from IIIMP would reach $22 \%$ [1]. There were other hopes to improve crop yields and reduce the irrigation cost as well. IIPs planned to improve water use efficiency by improving the conveyance efficiency through changing waterways in open Mesqas to pipelines, and by enhancing farmers' irrigation practices as the result of operational and institutional activities. Improving water availability should improve the crops yield, either through decreasing water crisis events or through decreasing the dependence on the unconventional water resources.

IIPs planned to reduce the irrigation cost as well. Aggregating scatter farmers' pumps in collective pumps at the head of the Mesqas was the first step. The second main step was the replacement of the diesel pumps by electric pumps. Regarding the change to electric power, Nour El-Din and Kotb (2006) stated, "Electric pumps option provides $10 \%$ savings in the cost of lifting each cubic meter of water when using financial prices. It also provides more than $29 \%$ savings under economic prices".

Previous evaluation results regarding the Impact of IIPs on Water, Energy and Food Elements

Many evaluation programmes were conducted to evaluate the achievement of IIPs targets. The main programme was the programme of Water Management Research Institute (WMRI) between 2002 and 2018.

Evaluations results showed that the only positive impact on water use was the improvement of the conveyance efficiency, which could save around 3\% of total water supply at the head of the command areas. This amount contribute to improve water availability at the tail end of the 
Mesqas [2]. There was an expectation that Marwas (on-farm ditches) improvement will double this amount of water saving.

Regarding the crop yield, the evaluation reports by Water Management Research Institute (WMRI) showed that the increase of the yield is associated with changing from the dependence on the drainage water to the dependence on fresh water. This happened at the tail ends of many Mesqas after the implementation of IIPs. The change in the source of the irrigation water in these areas increased the yield by $32 \%$ for wheat crop and by $30 \%$ for rice crop [15 \& 16].

In addition, WMRI evaluation results showed that the reduction in the irrigation cost after the implementation of IIPs was between $39 \%$ \& $75 \%$ for rice crop, between $40 \%$ \& $65 \%$ for maize crop, $\sim 65 \%$ for wheat crop, and between $70 \%$ and $85 \%$ for sugar beet crop [15 \& 16]. These studies were conducted in improved areas that depend on the electric power.

\section{Studying Area}

El-Atf canal is one of the main branches at the south of Middle Delta (El-Monofiya and Zefta irrigation directorates). The canal is at the end of Dalel El-Atf, which is a short entrance at km 28.96 on El-Monofy Rayah (figure 2). El-Atf canal is $48.6 \mathrm{~km}$ length and it serves 13,860 ha in three irrigation districts. The canal has twelve branches with served areas between 168 and 840 ha. The first reach of the canal (in Quesina irrigation district) is $15.0 \mathrm{~km}$ long and it has one branch (Mit El-Kosary). The total served area of this reach including Mit El-Kosary is 2,801 ha. As could be observed from figure (2), part of the served area of El-Atf canal is outside Quesna irrigation district (in El-Bagour irrigation district). Actual cross sections in the investigated reach were wider than design cross-sections.

Regarding irrigation improvement, there was a previous pilot project to improve the irrigation is a part of El-Atf canal in 1980s. The current Irrigation Improvement Project (IIP) started in 2006. Two hundreds and fifty-six Mesqas with total served area equals 6,504 ha were established during this project. The project contained replacing open Mesqas or scatter lifting points on the canal by single lifting points that are connected to 12 inches PVC pipelines, and alfa-alfa valves at the heads of different Marwas. IIP was implemented along the canal, but it faced many problems in downstream reaches. In the first reach (study area), the improved Mesqas were very steady, and in addition, farmers cooperated to improve the situation. They replaced the diesel pumps, or one of them, with electric pumps. Other farmers connected the improved Mesqas to shallow groundwater besides the surface water to ensure water availability during the whole year. Twelve improved Mesqas, between

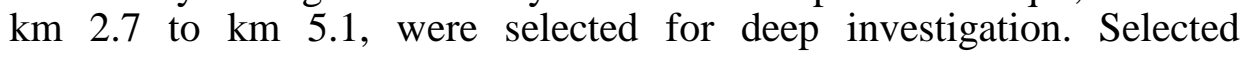


improved Mesqas serve areas between 18 and 50 hectare. Pumps' capacities were between $60.0 \& 90.0 \mathrm{l} / \mathrm{sec}$. Some pumps are diesel pumps and the other are electric pumps. The cultivated crops in this area are the traditional crops, such as maize, wheat, Barseem (Alfalfa), taro besides some vegetables and some orchards.

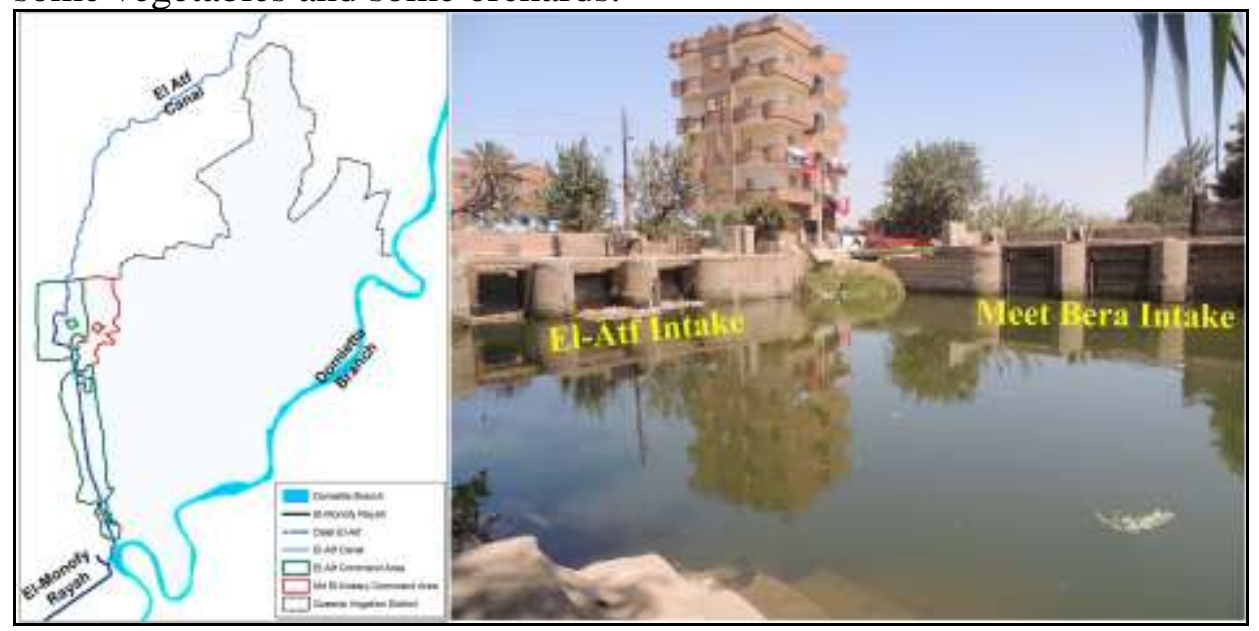

Figure (2): Schematic drawing for El-Atf canal with a photo for its head regulator

\section{Crop yield}

\section{RESULTS}

Increasing the yield in the improved areas is normally associated with the improvement of water supply, especially at the areas that had water crises or that were depending on polluted water before the improvement. This was not the case in the studying area, which located at the head region of El-Atf canal. Despites little dependence on shallow groundwater, surface water was sufficient and the main problem of the studying area was low water use efficiency.

The collected questionnaires from the farmers did not refer to any specific trend regarding crop yield improvement. Farmers' opinions indicated that the change in the crop yield is random, and it is related to agricultural and irrigation practices of different farmers more than being related to IIPs.

\section{Water use \& abstraction trends}

Improving water use efficiency was the main objective of implementing irrigation improvement projects. However, most of the evaluation results referred to a problem in achieving such target. In the studying area, which represent the head of the canal, water use was considerably high. From figure (3A), and considering the period from the beginning of April to the middle of August, irrigation efficiency was around $35 \%$. The big difference could be observed at the second half of 
April and during May (harvest time). The results refer to the necessity to calculate water requirements precisely and use it as the basis to operate the canal.

Another reason for low water use efficiency was in the low coordination between farmers. One of the objectives of IIPs was to distribute water through the day, and stop concentrating the irrigation in specific hours, which was the trend that started since using the diesel pumps in 1970's. Most of the evaluation results indicated that the previous situations were not changed after the implementation of IIPs. Figure (3B) presents an example about water abstraction by the selected Mesqas during five days of June 2018. Irrigation was concentrated between 9:00 AM and 12:00-13:00 PM, and the highest water abstraction values were between 0.7 to $0.9 \mathrm{~m}^{3} / \mathrm{sec}$. Average-water use during this period was $114.3 \mathrm{~m}^{3} / \mathrm{ha} /$ day, which is high value compared to normal irrigation water use during this time (April to Aug). The irrigation stopped completely for few hours around the midnight.

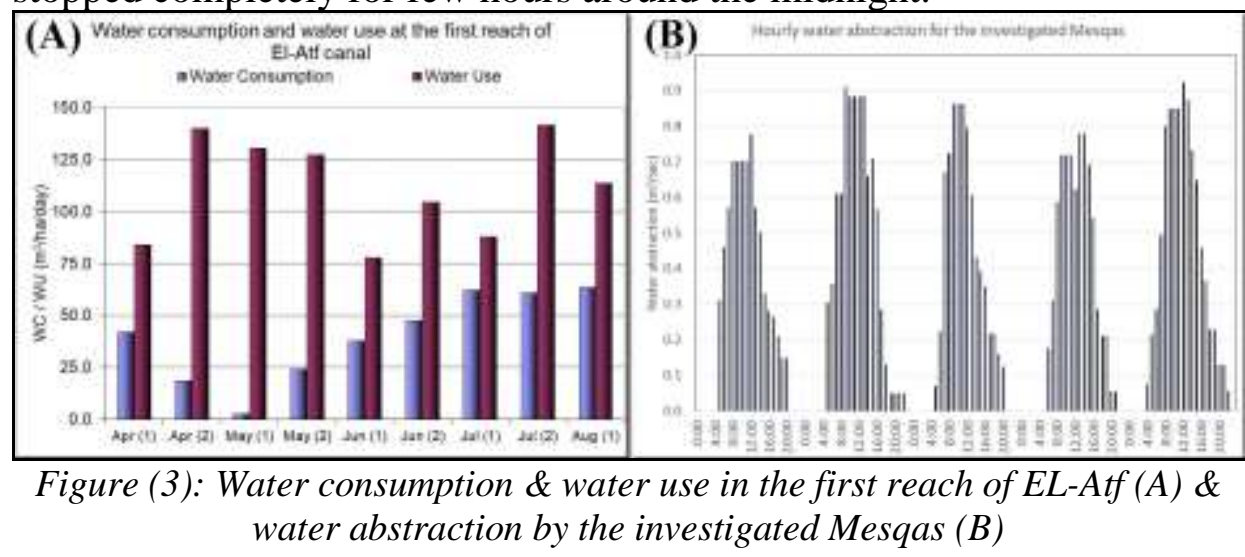

\section{Irrigation cost}

The improvement project replaced farmers' pumps with single-point lifting at the head of the Mesqas. The original pumps in the improved Mesqas in El-Atf canal were diesel pumps. In most of the improved Mesqas in the studying area, farmers replaced the diesel pumps, or at least one of them, with electric pump. The main reason was to have more than one source to face the energy crises, which escalated during the political instability period (after 2011). However, this had positive impact on reducing the cost.

Most of the evaluation results at different improved areas confirmed that IIPs had a positive impact of reducing the irrigation cost. For the studying area, and based on collected questionnaire samples, the reduction in the irrigation cost for maize crop was between $25 \%$ \& $75 \%$ 
with an average of $45.1 \%$. For winter crops, the average reduction in the irrigation costs were $13 \%$ for wheat and $35 \%$ for Barseem. The reduction in the irrigation cost for wheat was little because the cost in the improved Mesqas is shared based on the served areas regardless the crops. The irrigation cost for crops with low water requirements (like wheat) is normally low. While distributing the irrigation cost in the improved Mesqas based on the served areas, the average irrigation cost between low and high water consumption crops became close to the irrigation cost of low consumption crops before the improvement.

Regarding the second step to reduce the irrigation cost, which is the introduction of the electric pumps, an example (Mesqa 18/16) was used to illustrate the difference between the operation costs for diesel pumps and the electric pumps. All diesel pumps in this Mesqa were replaced by electric pumps, and therefore, it was easier to compare the operation cost between the two situations precisely. Table (1) presents the cost of both situations. Due to the rapid change in the energy prices, and to make a right comparison, the current prices of different items was used with the average consumption of these items. Regarding previous operation cost (diesel pumps), the average diesel consumption was 820 liter/month during 5 months (summer season), and 205 liter/month during 6 months (winter season), and the system was stopping for one month (closing period). In addition, the system was consuming 40 liter/month of oil for lubricant during summer months and 10 liter/month during winter months. The pumps were maintaining twice annually and the average cost for each maintenance was around 13000 L.E. The total cost for operating the Mesqa during this time was 63,115 L.E. The served area of the Mesqa was 50 hectare, and the annual share of each hectare was 1262.3 L.E. For the current operation cost (electric pumps), the average cost of recharging the electricity card is $1500.0 \mathrm{~L} . \mathrm{E} / \mathrm{month}$, and the average lubricant cost is around 360.0 L.E/year. Almost, there is no maintenance cost. The served area increased to 52.5 hectare, and the annual share of each hectare was 349.7 L.E, which is around $28 \%$ of the previous operation cost. Average irrigation cost for some farmers, who were not connected to the improved Mesqas, and who were depending on shallow groundwater, was $\sim 6500$ L.E./ha/year. The actual difference between total costs of diesel and electric pumps might be less than this example because there are common items that have the same costs in both systems like operator wage, and the maintenance of other items (like valves, etc.) 
Table (1): The operation cost of Mesqa 18-16 for diesel and electric pumps

\begin{tabular}{|c|c|c|c|c|c|c|c|c|c|}
\hline \multicolumn{5}{|c|}{ Previous operation cost (Diesel Pumps) } & \multicolumn{5}{|c|}{ Current operation cost (Electric Pumps) } \\
\hline & Unit & Amount & Price (L.E) & Total & & Unit & Amount & Price (L.E) & Total \\
\hline Diesel fuel & Liter & 5330.0 & 5.5 & $29,315.0$ & $\begin{array}{l}\text { Recharging the } \\
\text { electricity card }\end{array}$ & Month & 12.0 & 1500.0 & $18,000.0$ \\
\hline Lubricant oil & Liter & 260.0 & 30.0 & $7,800.0$ & \multicolumn{2}{|c|}{ Annual lubricant cost } & 1.0 & 360.0 & 360.0 \\
\hline \multicolumn{2}{|c|}{ Annual maintenance cost } & 2.0 & 13000.0 & $26,000.0$ & Annual maint & nance cost & 0.0 & 0.0 & - \\
\hline \multicolumn{4}{|c|}{ Total } & $63,115.0$ & \multicolumn{4}{|c|}{ Total } & $18,360.0$ \\
\hline \multicolumn{4}{|c|}{ Served area (feddan) } & 50.0 & \multicolumn{4}{|c|}{ Served area (feddan) } & 52.5 \\
\hline \multicolumn{4}{|c|}{ Annual share /feddan (LE) } & $1,262.3$ & \multicolumn{4}{|c|}{ Annual share /feddan (LF) } & 349.7 \\
\hline
\end{tabular}

Regardless the reduction in the cost with using the electric pumps in comparison to diesel pumps; the dependence on the electric pumps was limited in some Mesqas. As an example, in Mesqa (16/15), using the electric pump was limited because it is a big pump, and it requires opening four valves or more in the same time. Otherwise, water would overflow from the water tower. Because the served area of the Mesqa is relatively small (17.6 ha), opening many valves in the same time was not happen frequently, and the diesel pump (the small one) is used during most of the time. In the previous example (Mesqa 18/16), there are three motors: 20.0 HP, which requires opening at least eight valves, 15.0 HP, which requires opening at least three valves, and 7.5 HP, which could work with only one valve, and therefore there is no any problem with the number of the opened valves.

\section{DISCUSSION}

Considering the general situation in Egypt, the relation between water and food production seems very critical, and it will be more critical with rapid increase in water demand in the future. Energy came second as a control element for food production. It will affect the food cost, but no problem is expected regarding its availability.

Regarding the impact of irrigation improvement projects on water saving and irrigation cost:

T The project could improve the yield in some areas that depend on the polluted drainage water at the tail end of the Mesqas with improving of the equity of water distribution through these Mesqas. The impact at the tail end of branch canals is limited. The results expected 6\% water saving from improving the conveyance efficiency in both Mesqas and Marwas. With using this amount instead of the dependence on the drainage water, crop yield would increase with an average $30 \%$ as indicated in the previous results. This means that the general increase in crop yield could be $1.8 \%$

- For the energy, there was a reduction in the energy cost after the implementation of IIPs, but the irrigation cost constitutes a small ratio of the agricultural inputs. Therefore, the reduction in the 
irrigation cost has limited impact on the reduction of the food cost. As mentioned before, irrigation cost constitute between $4 \%$ and $10 \%$ of the agricultural inputs. Considering that IIPs could reduce the irrigation cost by $50 \%$ in average, total agricultural inputs will be decreased by $2 \% \sim 5 \%$. The fluctuation in agricultural inputs and food transportation and in crops yield might have higher impact than this ratio. Through the evaluation of IIPs, farmers rejected the idea to distribute the irrigation cost (in the improved Mesqas) based on the operation hours instead of distributing it based on the cultivated area [15 \& 16]. In addition, the results showed that some improved Mesqas in the studying area were still depending on the diesel pumps although the electric pumps have good reduction in the irrigation cost. This indicated that the irrigation cost is not a serious element for the farmers

Enhancing the impact of IIPs will be through improving water distribution in the improved areas. IIPs was conducted with an intention to distribute the water between branch canals based on actual requirements and with volumetric basis, while scheduling the operation of the improved Mesqas. However, the real implementation was far from this.

There is a research project going on in the studying area to calculate the actual crop requirements for different improved Mesqas or served areas based on remote sensing information, and distribute the water between these Mesqas / areas with a model that will be designed for this purpose. Such approach, if it could applied, should improve water management in the study areas.

\section{CONCLUSION}

Producing food with the optimal use of water and energy became an essential issue with the fast growing of population and the limitation of water and energy resources. Irrigation improvement projects were a trail to provide a solution for the limitation of water and energy resources.

IIPs had limited impact on improving water use efficiency and crop yields, and although the impact on reducing the irrigation cost was significant, the share of the irrigation cost for the agricultural inputs is little, and this is reflected on its importance. More attention should be given to improve water distribution to decrease the dependence on reusing unconventional water resources, which have negative impact on crop yield and it is associated with health risks.

Improving water distribution strategies could be the fast solution in near future to decrease the dependence on the reuse. Enhancing the treatment of sewage and industrial wastes is the second main step, for safe use of these huge amounts. The country is currently taking care of 
this topic seriously. The final step will be the desalination of the brackish water, and the technologies to cultivate using this brackish water.

The relation between crop production and irrigation cost in Egypt will be also changed by the current reclamation projects, which depend on deep groundwater, and it is associated with high water-lifting cost. It will be also affected by using the solar energy in irrigation that has started, and will spread in the future, and this might require deep investigations.

Acknowledgement: This research was supported by Science and Technology Development Fund - Egypt (Project \# 26318)

\section{REFERENCES}

1. El-Gamal, T. T. (2011): Evaluating the Improved Irrigation Networks in Egypt. Journal of soil science and agricultural engineering. Mansoura University., 2 (8).

2. El-Gamal, T. T.(2018): Investigating the Impact of Irrigation Improvement Project on Water Saving. International Journal of Engineering Research and Allied Science (IJERAS). , 3 (3):

3. El-Gamal, T. T. (2018): Examining an Egyptian Irrigation Network using MASSCOTE Approach. Journal of soil science and agricultural engineering. Mansoura University.,9(2).

4. FAO, Food and Agricultural Organization (2019). http://www.fao.org/egypt/programmes-and-projects/food-losswaste-reduction/en/

5. Hemdan, G. (1984): Personality of Egypt, vol. 3. PP. 244 \& PP. 269 (Arabic)

6. Hussein, A. and El Baz, M. (2018): Egypt's Natural Gas: Bright Prospects. (October 2018) https://egyptoilgas.com/reports/egypts-natural-gas-bright-prospects/

7. Mady, A.M. (2014). The Food Gap in Egypt during the period (2010-2020). Scientific Journal of Business and Environmental Studies (Arabic)., 4: 287-312

8. Ministry of Agricultural and Land Reclamation (MALR) (2018):- Economic Affairs Sector. Bulletin of the Agricultural Statistics. Summer and Nili Crops 2015-2016. January 2018

9. Ministry of Electricity and Renewable Energy -MEE. (2019): ( Annual Electric Reports. http://www.moee.gov.eg/english_new/report.aspx: 2018/2019

10. Ministry of Irrigation.(1979): Irrigation Development Plan in Egypt. August 1979 (Arabic). PP. 114-115

11. Ministry of Water Resources and Irrigation - MWRI. (2017): National Water Resources Plan 2017 - 2030 - 2037. July 2017 (Arabic). PP. 15 
Egypt. J. of Appl. Sci., 35 (11) 2020

12. Nour El-Din, M. and T. Kotb (2006): Energy for Irrigation in Egypt's Old Lands. 3rd International Conference on Water Resources in Mediterranean Basin, Tripoli, Lebanon, 1-3 Nov 2006

13. Water Management Research Institute - WMRI.(2008): Monitoring and Evaluation of Irrigation Improvement Project (IIP1) - Final report - May 2008

14. Water Management Research Institute - WMRI.(2014): Monitoring and Evaluation of Integrated Irrigation Improvement and Management Project - Final report for the period from summer 2008 to winter 2013-14 - May 2014

15. Water Management Research Institute - WMRI.(2017): Monitoring and Evaluation Program for Integrated Irrigation Improvement \& Management Project (IIIMP) - Winter 20162017. July 2017

16. Water Management Research Institute - WMRI. (2017): Monitoring and Evaluation Program for Integrated Irrigation Improvement \& Management Project (IIIMP) - Summer 2017. November 2017

$$
\begin{aligned}
& \text { تقييم تأثير مشاريع تظوير الري على توفير المياه } \\
& \text { وإنتاجية المحاصيل وتكلقة الطاقة } \\
& \text { ( دراسة حالة - ترعة العطف، مصر) }
\end{aligned}
$$

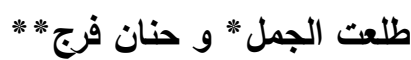

$$
\begin{aligned}
& \text { * أستاذ باحث مساعد - معهد بحوث إدارة المياه - المركز القومي لبحوث المياه } \\
& \text { ** أستاذ باحث مساعد - المركز القومي لبحوث المياه }
\end{aligned}
$$

تعاني مصر من محدودية الموارد المائية ، كما عانت مصر من بعض المضاه المشكلات المنعلقة

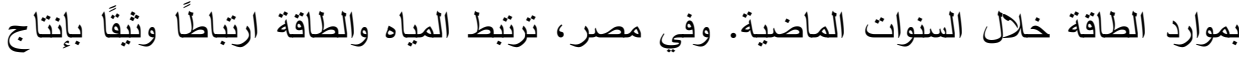

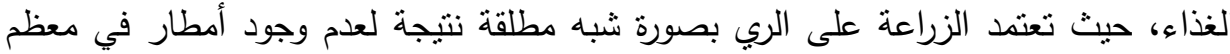

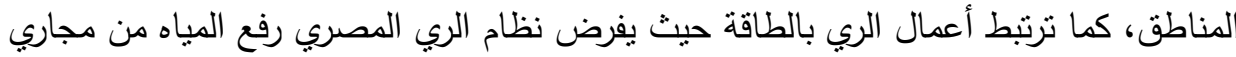

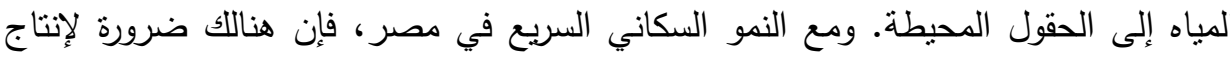
المزيد من الغذاء، وهذا يتطلب الاستخدام الأمنل لموارد المياه والطاقة المحدودة.

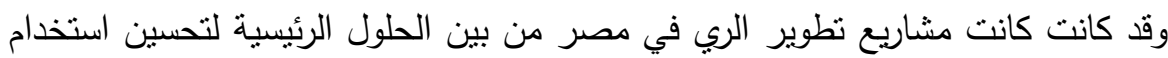

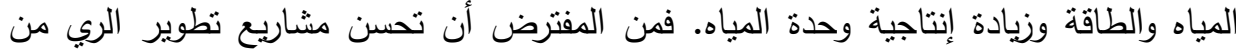
إنتاجية وحدة المياه وذللك من خلال تحسين كفاءة استخدام المياه وزيادة إنتاجية المحاصيل.

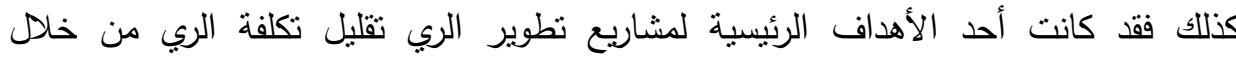

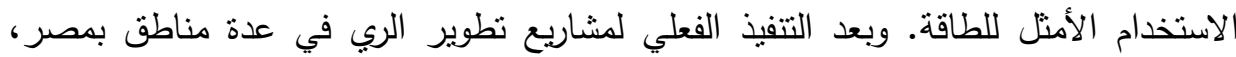


أشارت بعض برامج التقييم والمتابعة إلى وجود صعوبات في تحقيق بعض الأهداف، في حين تحققت أهداف أخرى بنجاح.

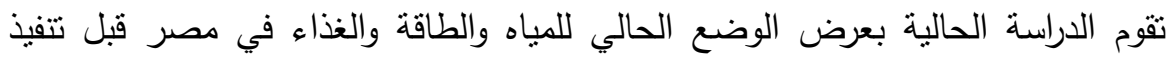

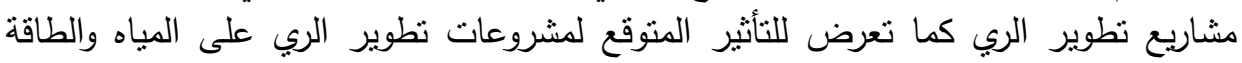

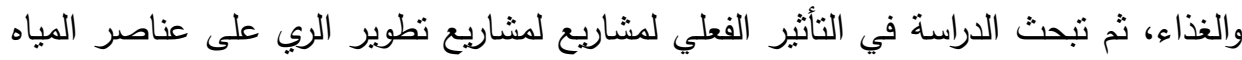

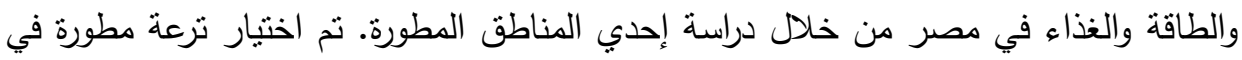

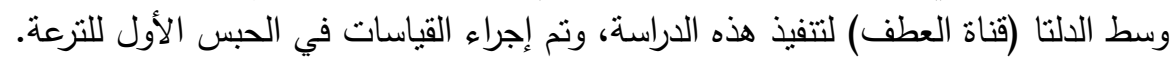

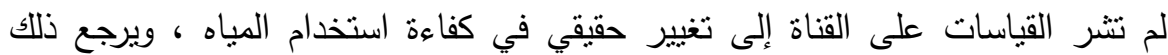

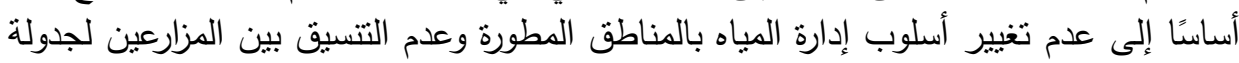

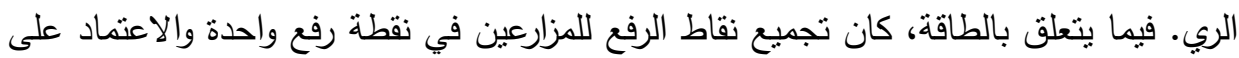

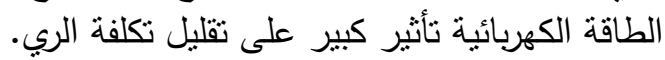

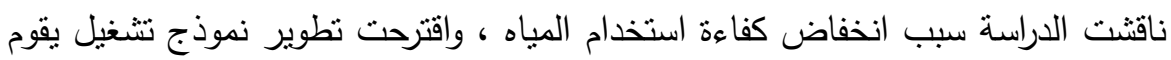

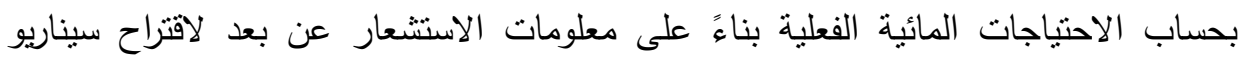

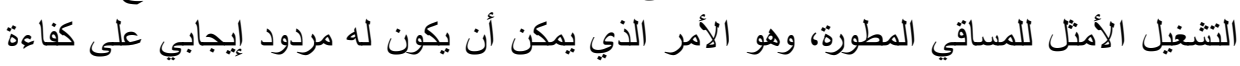
استخدام المياه وعلى تكلفة الري. 